NBSIR 86-3453

\title{
Plan for A Design Study for A National Earthquake Engineering Experimental Facility
}

Charles F. Scribner

E. V. Leyendecker

U.S. DEPARTMENT OF COMMERCE National Bureau of Standards National Engineering Laboratory Center for Building Technology Gaithersburg, MD 20899

October 1986

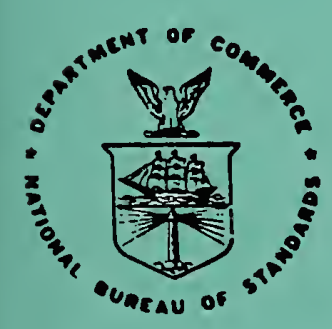

U.S. DEPARTMENT OF COMMERCE NATIONAL BUREAU OF STANDARDS

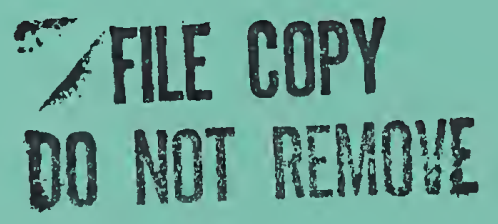



NBSIR $86-3453$

PLAN FOR A DESIGN STUDY FOR A

NATIONAL EARTHQUAKE ENGINEERING

EXPERIMENTAL FACILITY

Charles F. Scribner

E. V. Leyendecker

U.S. DEPARTMENT OF COMMERCE

National Bureau of Standards

National Engineering Laboratory

Center for Building Technology

Gaithersburg, MD 20899

October 1986

U.S. DEPARTMENT OF COMMERCE, Malcolm Baldrige, Secretary NATIONAL BUREAU OF STANDARDS, Ernest Ambler, Director 
PLAN FOR A DESIGN STUDY FOR A

NATIONAL EARTHQUAKE ENGINEERING EXPERIMENTAL FACILITY 


\section{ABSTRACT}

This report describes the work plan for a four-phase study to determine the needs for and design details of a national earthquake engineering research facility. The need for data on the behavior of full-scale buildings and building components was recognized by the National Research council in the report "Earthquake Engineering Facilities and Instrumentation", which was produced by the NRC ad hoc Committee on Earthquake Engineering Facilities and Instrumentation in 1984. This report discusses in detail the study NBS will conduct in cooperation with the Federal Emergency Management Agency, the National Science Foundation, the Unites states Geological Survey, and other agencies. 
TABLE OF CONTENTS

Page

ABSTRACT

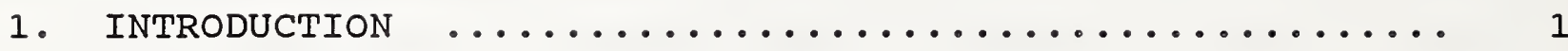

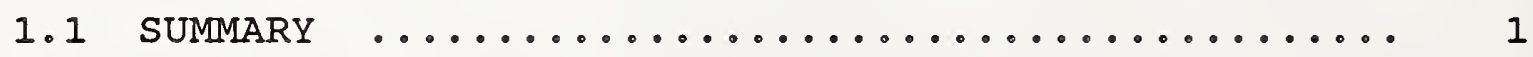

1.2 BACKGROUND $\ldots \ldots \ldots \ldots \ldots \ldots \ldots \ldots \ldots \ldots \ldots \ldots \ldots \ldots \ldots \ldots \ldots$

1.3 OBJECTIVES AND SCOPE OF STUDY $\ldots \ldots \ldots \ldots \ldots \ldots \ldots . \ldots$

1.4 NATIONAL RESEARCH COUNCIL ADVISORY PANEL $\ldots \ldots \ldots .6$

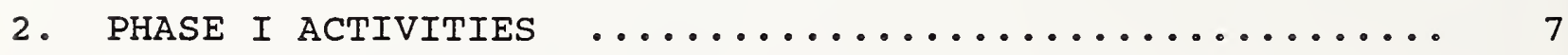

2.1 OBJECTIVES AND SCOPE $\ldots \ldots \ldots \ldots \ldots \ldots \ldots \ldots \ldots \ldots \ldots$

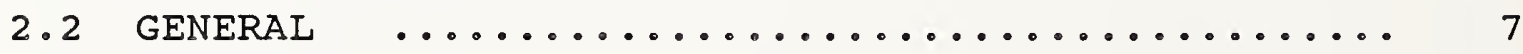

2.3 TASK ONE - BACKGROUND STUDY $\ldots \ldots \ldots \ldots \ldots \ldots \ldots$

2.4 TASK TWO AND TASK THREE $\ldots \ldots \ldots \ldots \ldots \ldots \ldots \ldots$

2.4.1 RESEARCH AND USER NEEDS STUDIES $\ldots \ldots \ldots \ldots .8$

2.4.2 RESEARCH AND USER NEEDS WORKSHOP $\ldots \ldots \ldots .11$

2.4.3 PUBLICATION OF SUMMARY OF FINDINGS BY NBS • 14 
3. SUMMARY OF ACTIVITIES - SECOND THROUGH FOURTH YEARS .. 15

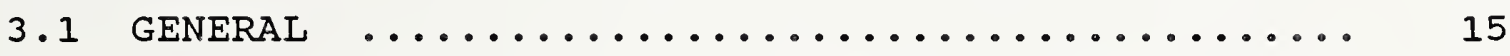

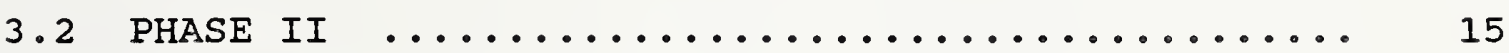

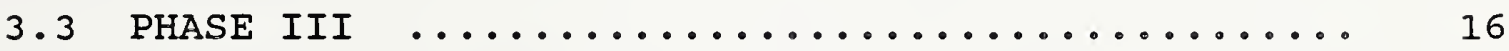

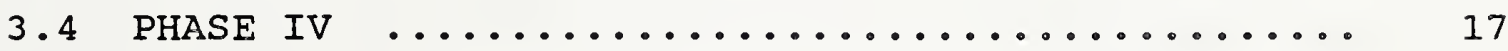




\section{INTRODUCTION}

\subsection{Summary}

This report describes the work plan for a four-phase study of needs for and design of a national earthquake engineering experimental facility. Each phase of the study will last about one year. Particular attention is being paid in this document to activities in the first phase of the study. Details of the work proposed for the second through fourth phases of the study are subject to change as work progresses and findings of the study become available.

\subsection{Background}

In 1984, the National Research Council (NRC) published the results of its 6-month study on "Earthquake Engineering Facilities and Instrumentation" requested by the office of Science and Technology Policy (OSTP). 1 The report contains a number of conclusions, including the following:

* "There is near unanimity within the earthquake engineering community that a need exists for data on the behavior of earthquake-excited full-scale multistory structures from the

1 Ad Hoc Committee on Earthquake Engineering Facilities and Instrumentation, Commission on Engineering and Technical Systems, National Research Council, Earthquake Engineering Facilities and Instrumentation, NationalAcademy Press, Washington, D. C., 1984, $33 \mathrm{pp}$. 
initiation of structural damage to collapse.

* "The irreducible need for full-scale data on the behavior of earthquake-impacted multistory structures requires that the nation have experimental facilities able to test such structures across a range from damage initiation to collapse. At present, no adequate facilities for testing full-scale structures exist in the United States. A variety of alternative experimental/test facilities have been proposed. These include shaking tables, reaction walls, instrumented buildings in earthquake-prone areas, explosive tests, and tests on prototype structures."

One of the major recommendations of the report with regard to this latter conclusion was that "The Federal government should undertake, on an accelerated basis, planning aimed at developing a major national earthquake engineering experimental/test facility. The goals of that facility should be to provide the data and understanding necessary for rapid improvement in the design and construction of seismic-resistant structures."

The Science Advisor to the President urged the Federal Emergency Management Agency (FEMA) to initiate the planning study called for in the NRC report and to obtain information which can be used as the basis for a decision on the need for and the requirements of a national earthquake engineering experimental facility. At 
the request of FEMA, the Policy Coordination Group (PCG) of the National Earthquake Hazards Reduction Program (NEHRP) considered the scope of a planning study and the alternatives for funding the study.

The PCG recommended that the National Bureau of Standards (NBS) proceed with the planning study. The PCG also recommended that, due to budgetary constraints, the study be conducted in four phases over approximately a four-year period. This time frame includes a series of decision points at which the PCG will determine whether remaining phases of the study should be carried out.

The study is a cooperative effort of FEMA, NBS, the National Science Foundation (NSF), and the U. S. Geological Survey (USGS). Principal funding and coordination is being provided by FEMA, and NBS is conducting the study. NSF is also providing financial support. All four agencies will participate in frequent planning sessions as the study proceeds. 
1.3 Objectives and Scope of Study

The objectives of the complete study are the following:

* Define the data needed on full-scale ${ }^{2}$ structural behavior

* Define the type of facility (large shaking table, reaction wall, etc.) needed to obtain required data

* Identify the potential users $^{3}$ of such a facility

* Identify sources of public and private support for construction and operation of the facility

* Define siting, operational, and funding requirements of the facility

* Evaluate cost effectiveness of a full-scale test facility with respect to alternative data sources

* Achieve credibility of the findings and recommendations in the professional, earthquake, scientific, and national

2 Full-scale is used in this report to mean full-scale or nearly full-scale in size.

3 "Users" will be interpreted in the broad sense to include both users of the facility and users of information generated by the facility. The NRC study pointed out that "users" includes both researchers and practitioners. 
policy communities

* Formulate the study to allow it to be updated readily in the event that action on the recommendations is delayed

This study has been divided into four phases. Phase I will address research needs and priorities. This includes determination of critical data needs on full-scale structural behavior, development of a multi-year ${ }^{4}$ program of experimentation and testing, and development of the requirements for a facility to conduct that program of experiments. Subsequent phases will include a preliminary design and estimation of the cost of a large shaking table (Phase II), a study of costs of alternative types of facilities (Phase III), and a study of siting, operational, and management requirements (Phase IV). Each of the four phases is a complete study to satisfy the PCG needs for information it can use to make its decisions. Phases I, II, III, and IV are scheduled for the first, second, third, and fourth years, respectively; however, their scope and sequence are subject to review on completion of each phase.

4 The NRC report suggested a three to four year program. This period is used in this report but may be modified during the course of the study. 


\subsection{National Research Council Advisory Panel}

At the request of the four principal agencies, the National Research Council has established a panel to review and comment on the procedures being used to conduct the study. The responsibilities of the NRC Panel during Phase I will include the following:

* Review and comment on work plans, direction and progress of the study, drafts of publications, and other critical documents

* Provide recommendations regarding scope of study and feasibility of elements of proposed study

* Attend user needs workshop at which results of studies will be presented

* Review and comment on results of studies conducted by project participants

* Provide an independent statement, based on the knowledge and experience of panel members, on user needs 
2. PHASE I ACTIVITIES

2.1 Objectives and scope

The objectives of the work planned during Phase I, the first year of the study, are the following:

* Summarize existing information regarding the necessity for a national earthquake engineering experimental facility

* Determine the needs of potential users of the facility

* Determine critical data needs on full-scale structural performance

* Develop an experimental program of at least three to four year duration that will satisfy current perceived needs for data on behavior of full-scale structures and will require testing facilities not available now

\subsection{General}

During the first year of the study, three tasks will be performed: 1) conduct a background study to summarize existing information regarding the necessity for a national earthquake engineering experimental facility; 2) conduct studies to determine the 
critical data on large-scale structural performance needed by owners, manufacturers, builders, designers, researchers, and other potential users of such a facility, and 3) develop an experimental program of at least three to four year duration, including associated facility requirements. The first task will be done by NBS personnel; the second and third tasks will include participation by others under the guidance and direction of NBS. Details of these three tasks follow.

\subsection{Task one - Background study}

The National Science Foundation and other agencies have previously sponsored workshops which have considered needs for large scale testing facilities and large shaking tables. The background study will include a review of these workshops and will summarize their findings. This summary will be published at the conclusion of the first year of the study.

2.4 Task Two (Research and User Needs Study) and Task Three (Development of Experimental Program)

2.4.1 Research and User Needs Studies

The most important objectives of the first year of this study will be to determine the needs of users for a national earthquake engineering experimental facility and to develop an experimental 
program of three to four year duration for the facility. NBS staff will participate actively in this task and in preparation of the report.

Portions of the study will be conducted under a series of contracts by technical and professional experts and organizations that represent fields of anticipated users of a national facility. The areas of interest include experimental work needed to provide the data and understanding necessary for rapid improvement in the design and construction of seismic-resistant structures. Particular emphasis will be placed on multistory buildings and other structures requiring similar testing facilities. Other structures may include those for electric power, lifelines, petrochemical and chemical industries, mechanical equipment, dams, and tunnels and other underground structures. The selected organizations and individuals will conduct simultaneous studies to satisfy the requirements of both Task Two and Task Three.

The contractors will be responsible for the following:

* Determine critical and minimum information needed to improve understanding of the performance of structures during earthquakes which could be provided by a full-scale testing facility, but which could not be provided by existing smaller facilities. This information will be used as a 
basis for the required research plan and facility size and configuration recommendations cited in following elements of the scope of the study.

* Determine the characteristics of a testing facility needed to obtain the critical data identified above.

* Develop details of a five year program of experimentation using a full-scale test facility which would provide the critical data identified above. This should include the following elements for each problem identified:

1) A description of the technical problem to be considered.

2) The nature of the test required to represent accurately the structural response of the structure being considered (i.e., dynamic, static, pseudo-dynamic, etc.).

3) The size and general configuration of the test specimen required (i.e., individual components, subassemblages, or complete structures, etc.).

4) An estimate of the magnitude of the loads required to test the specimens realistically.

The contractors shall submit a plan describing the procedure to be used to develop their recommendations. 
Based on these contracts, NBS will prepare a draft report on experimental needs and priorities. This report will be reviewed at a workshop as described in section 2.4.2.

\subsubsection{Research and User Needs Workshop}

The objective of this task is to evaluate the specific needs of various fields of earthquake engineering for a national research facility which will allow the conduct of tests which cannot be carried out at existing facilities. The results of the individual studies and the NBS draft report on the study results will be presented at a workshop. Workshop participants may include, among others, the following organizations:

* EERI - Earthquake Engineering Research Institute, representing researchers, practitioners, and manufacturers having expertise concerning and a commitment to earthquake engineering research.

* SEAOC - Structural Engineers Association of California, representing a major body of practitioners having an interest in earthquake engineering and design of structures to resist earthquakes.

* ASCE - American Society of Civil Engineers, representing a broad spectrum of civil engineers and other persons 
similarly qualified in another branch of engineering or in an allied profession.

* Other organizations representing potential users of the facility and users of the results of research conducted in the facility, including the Building Seismic Safety Council, the American Society of Mechanical Engineers, the National Research Council, the Applied Technology Council, the University Council on Earthquake Engineering Research, the American Institute of Architects, the American Association of State Highway and Transportation officials, representatives of federal agencies, industry, and trade and manufacturer organizations such as the National Electrical Manufacturers Association, the American Gas Association, the Electrical Power Research Institute, the National Concrete Masonry Association, the Brick Institute of America, the American Iron and steel Institute, the American Institute of steel Construction, the Portland Cement Association, the Prestressed Concrete Institute, and others. 
The contractors and other invited professionals will also participate in the workshop. NBS will produce a draft summary report based on the findings of the workshop. Preparation for and conduct of the workshop will include the following activities:

* Preliminary meeting of contractors immediately following the award of contracts to ensure that all participants will produce results which will accurately evaluate the research or testing needs in their specific field.

* NBS review and approval of work plans proposed by contractors.

* Presentation of findings at NBS workshop. Contractors will present a summary of their findings at the workshop.

* Presentation of NBS draft at workshop. The preliminary draft of NBS findings summarizing the findings of contractors will be presented for comments from all workshop participants.

* Collection of comments received at workshop. Comments will be documented and used to modify the final report discussed in section 2.4 .3 of this report. 
2.4.3 Publication of Summary of Findings by NBS

A single report will be prepared to summarize the findings developed at the workshop. The preparation of this document will begin immediately following the workshop and will be modified as necessary to include additions or revisions made to the participants' final reports. This document will also be submitted to advisory groups for comment and possible modification prior to publication and will summarize findings on the following:

* Critical data that is needed on performance of full-scale structures during earthquakes and that cannot be determined by existing facilities

* Recommendation of a three-to-four-year experimental program designed to meet perceived needs

NBS will also submit the summary of its findings to the NEHRP Policy Coordination Group. The PCG will consider the recommendations in reaching its: decision on the continuation of the present four-year study. 
3. SUMMARY OF ACTIVITIES - SECOND THROUGH FOURTH YEARS

\subsection{General}

The total study is divided into four consecutive phases. Each phase of the study will be a cooperative effort of FEMA, NBS, NSF, and USGS and will seek input from a broad spectrum of industry, practicing engineers, government agencies, and organizations representing manufacturers and potential users of a national facility.

The first phase of the study has been described in section 2 . The activities carried out in the second through fourth phases of the study are described in this section. The sequence, schedule, and objectives of each future phase of the study will depend on findings and recommendations of the preceding phases. As each phase of the study is completed, the organization of subsequent phases may be changed to gain increased benefits from those phases.

\subsection{Phase II}

Phase II of the study will consist of a preliminary design and cost estimate of a shaking table and associated facility large enough to satisfy the needs identified in Phase $I$. The cost estimate will be used to determine cost-effectiveness of the 
shaking table in comparison with other alternatives. This will be done in response to the recommendations of the NRC study, which noted that:

"Although simultaneous study of alternatives is recommended, they are not given the same weight because, of all options, the large shaking table is the one with the least available engineering data. It is also the most complex and expensive. Detailed studies of other methods are not of high priority because more reliable data and real world experience are available in most cases."

Participants in this phase of the study will consider a variety of options for the shaking table facility, including different configurations for the laboratory, selection of equipment and sources of power for the laboratory, selection of instrumentation for the laboratory, and many other considerations.

\subsection{Phase III}

The objective of Phase III of the study will be to identify and compare alternative means of satisfying the requirements developed in the first phase of the study. One of these alternatives will be a large shaking table. The NRC study also identified other alternatives, including a large reaction wall, instrumentation of buildings in earthquake-prone areas, use of explosives, 
and tests of prototype structures. Participants in this phase of the study will be encouraged to explore these and other possible alternatives to determine which are most advantageous and cost-effective. Phase III may be conducted in concert with Phase II if sufficient funding is made available.

\subsection{Phase IV}

Phase IV of the study will be to determine siting, operational, and management requirements for the facility selected during the third phase of this study. Phase IV will include consideration of requirements of users in the earthquake community, environmental requirements for siting, and estimates of cost-effectiveness for alternative sites, operations, and management plans. 
U.S. OEPT. OF COMM.

BIBLIOGRAPHIC DATA

SHEET (See in structions)

4ITLE AND SUBTITLE
1. PUBLICATION OR

REPORT NO.

NBSIR $86-3453$
2. Performing Organ. Report Nof 3. Publication Date

OCTOBER 1986

PIAN FOR A DESIGN STUDY FOR A NATIONAL EARTHQUAKE ENGINEERING EXPERTMENTAL FACILITY

5. AUTHOR(S)

Charles F. Scribner - E. V. Leyendecker

6. PERFORMING ORGANIZATION (If joint or other than NBS, see instructions)

NATIONAL BUREAU OF STANDARDS

DEPARTMENT OF COMMERCE

WASHINGTON, D.C. 20234

7. Contract/Grant No.

$E M N-85-E-2134$

9. SPONSORING ORGANIZATION NAME AND COMPLETE ADDRESS (Street, City, Stote, ZIP)

8. Type of Report \& Period Covered

Federal Emergency Management Agency

Washington, DC 20472

10. SUPPLEMENTARY NOTES

$\square$ Document describes a computer program; SF-185, FIPS Software Summary, is attached.

11. ABSTRACT (A 200-word or less factual summary of most significant information. If document includes a significant bibliogrophy or literoture survey. mention it here)

This report describes the work plan for a four-phase study to determine the needs for and design details of a national earthquake engineering research facility. The need for data on the behavior of full-scale buildings and building components was recognized by the National Research Council in the report "Earthquake Engineering Facilities and Instrumentation", which was produced by the NRC ad hoc Camittee on Earthquake Engineering Facilities and Instrumentation in 1984. This report discusses in detail the study NBS will conduct in cooperation with the Federal Emergency Management Agency, the National Science Foundation, the United States Geological Survey, and other agencies.

12. KEY WORDS (Six to twelve entries; alphabetical order; capitalize only proper names; and separate key words by semicolons) Earthquake; Experimental; FEMA, Full-scale; National Facility; Seismic; Study

$\square$ Order From Superintendent of Documents, U.S. Government Printing Office, Washington, D.C. 20402.

[X] Order From National Technical Information Service (NTIS), Springfield, VA. 2216I

14. NO. OF

PRINTED PAGES

24

15. Price

$\$ 9.95$ 


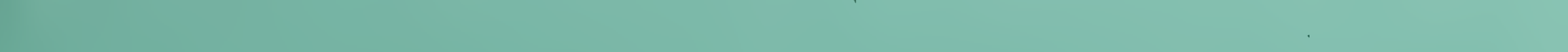


